\title{
Foraminiferal biostratigraphy of the Woo Dale Borehole, Derbyshire and the age of the Dinantian-Basement unconformity
}

\author{
A. R. E. STRANK
}

\begin{abstract}
Detailed micropalaeontological analysis of the Woo Dale Borehole shows that Dinantian strata of Holkerian and Arundian age lie unconformably on top of the preCarboniferous basement beds. The Chadian and Tournaisian are missing. The chronostratigraphy here recognised is compared with that proposed by Cope (1973) and the differences in the two interpretations explained in the light of recent palaeontological and Midlands regional research.
\end{abstract}

\section{INTRODUCTION}

Only two deep boreholes, namely Eyam and Woo Dale, have penetrated the complete Dinantian succession on the Derbyshire Dome. During the Dinantian, North Derbyshire was a shallow shelf province depositing thick richly bioclastic limestone sequences off the northern shores of St. George's Land (Fig. 1). To the east of the area a basinal embayment known as the Edale Gulf penetrated the Midlands shelf, depositing shales, sandstones and muddy limestone bands. The area was pulsed by a series of shallow marine events depositing sediments across the submerged areas. A series of local basement highs coupled with differential subsidence resulted in local non sequences caused by non deposition or erosion. The very thick Dinantian succession at Eyam (1803. $25 \mathrm{~m}$ ) contrasts markedly with that proven in the Woo Dale Borehole $(273.60 \mathrm{~m}), 11 \mathrm{~km}$ to the W.S.W. illustrating the consequences of different local conditions within an extensive shelf environment.

The Woo Dale Borehole drilled by I.C.I. in 1947-48 was situated on an anticlinal crest at the confluence of Woo Dale and Wye Dale $5 \mathrm{~km}$ east of Buxton (SK 4099 $3726)$ and was spudded into Woo Dale Limestone. The borehole was cored throughout having a diameter of $0.2 \mathrm{~m}$ at the top reducing to $0.04 \mathrm{~m}$ at the base.

The surviving core is housed in the Geology Departments at Keele, Manchester and Reading Universities with the remainder in the care of Professor F. W. Cope. Much of the limestone to $243.20 \mathrm{~m}$ is heavily dolomitised and most of the original texture and fossils have been destroyed by recrystallisation. Plentiful corals, brachiopods, foraminifera and algae occur in the less severely dolomitised horizons. Below $243.20 \mathrm{~m}$ dolomitisation is only slight and from $266.91 \mathrm{~m}$ to the top of the breccia at $271.16 \mathrm{~m}$ the limestones are less altered (Cope, 1973).

The brecciated horizons contain waterworn fragments of volcanic rocks indicating penecontemporaneous erosion at the base of the limestone succession (Cope,
1973). A possible deepening of basement from Woo Dale $(273.60 \mathrm{~m})$ to Eyam $(1803.25 \mathrm{~m})$ corresponds to a descent in the gravity anomaly over the area (Cope, 1973). Cope interprets this as a condensed sequence, a view he supports by the presence of clay band breaks in the succession, the intense dolomitisation and the fabric of the non dolomitised limestones (Cope, 1973). He concludes that differential subsidence of the North Derbyshire basement during the Dinantian is the mechanism responsible for the thickness change.

Cope's (op.cit.) biostratigraphical analysis of the macrofauna suggests $S_{2}$ (Holkerian) strata to a depth of $110.20 \mathrm{~m}, \mathrm{C}_{2} \mathrm{~S}_{1}$ (Arundian-Chadian) strata to $243.20 \mathrm{~m}$ and a probable ? $\mathrm{C}_{1}$ Zone (Tournaisian) to $273.60 \mathrm{~m}$. This paper presents a revised interpretation of the biostratigraphy together with palaeoenvironmental interpretation to explain the thickness changes between Eyam and Woo Dale.

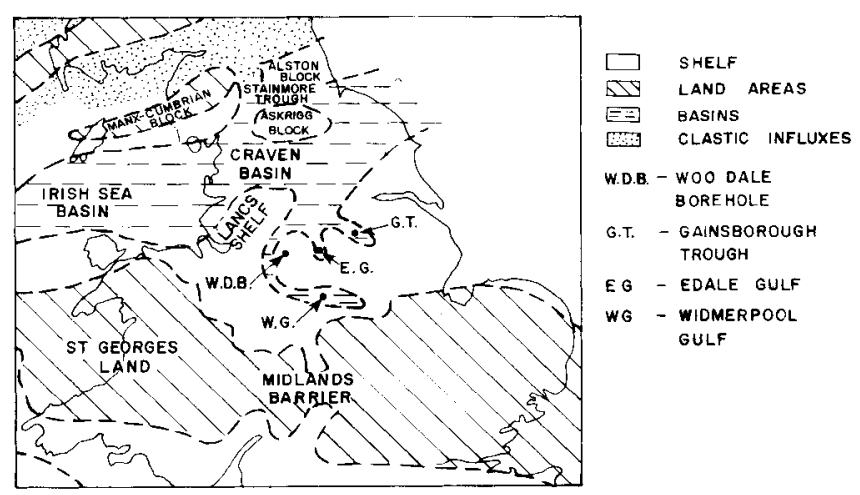

Fig. 1. Generalised Dinantian palaeogeographical setting of the Midlands area. 


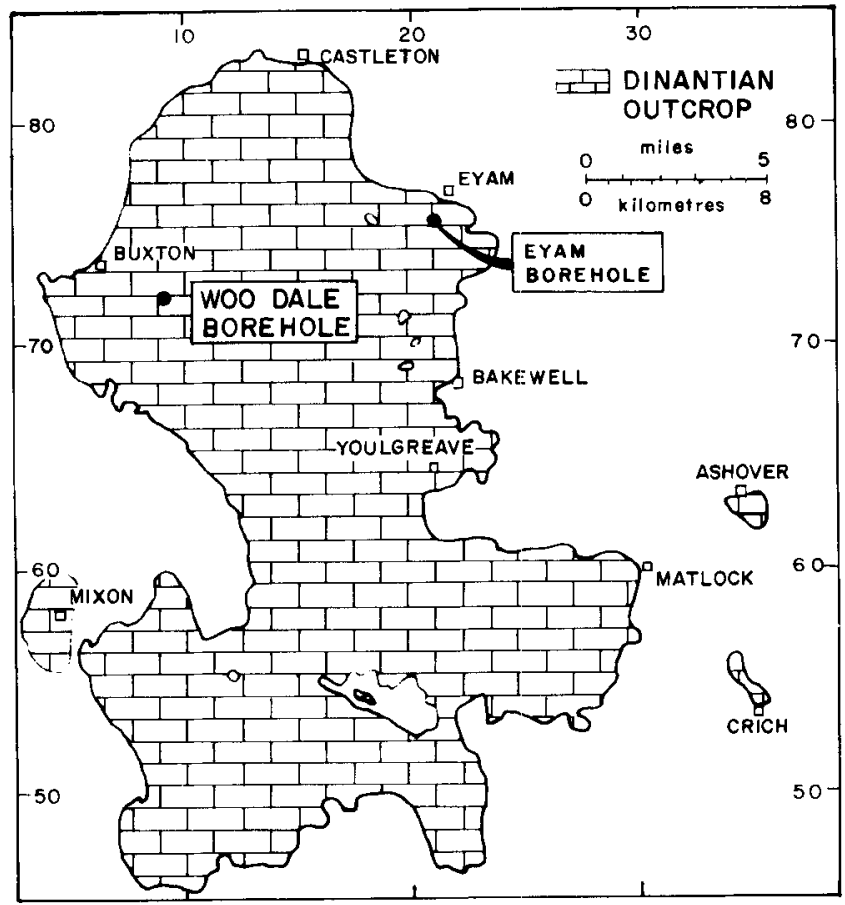

Fig. 2. Location of the Woo Dale Borehole and areas of Dinantian outcrop in the Derbyshire area.

\section{BIOSTRATIGRAPHY}

The microfossil data presented result from examination of thin sections cut throughout the borehole. This includes a collection of slides donated by Professor F. W. Cope for examination by the author. The macrofaunal occurrences recorded are taken from the detailed logs compiled by Professor Cope during the sinking of the borehole and from recent examination of coral sections by Mr. M. Mitchell (B.G.S., Keyworth). No palynological information is available.

\section{Microfossil Analysis (Fig. 3)}

$0-115.97 \mathrm{~m}$ : Holkerian

A rich, diverse microfossil assemblage together with some well preserved corals and brachiopods characterise the predominantly grey/brown dolomitised limestones found in this interval.

The presence of Nibelia nibelis (Durkina, 1959), Koskinotextularia sp., Bogushella sp., Eostaffella parastruvei (Rauser, 1948), Archaediscus stilus Grozdilova \& Lebedeva and Plectogyranopsis convexa (Rauser, 1948), together with the alga Koninckopora inflata (de Koninck) confirms a Holkerian age for this interval. A rich influx of calcispheres and ostracods, excluding all other fauna is recorded at $114.3 \mathrm{~m}$.

The accompanying corals inclucle Lithostrotion sociale, Haplolasma subibicina (McCoy) and Syringopora cf. ramulosa Goldfuss. Amongst the brachiopods present
Davidsonina carbonaria (McCoy) and Composita cf. ficoides (Vaughan) confirm a Holkerian age. A record of Daviesiella llangollensis (Davidson) at $26.01 \mathrm{~m}$ indicates Holkerian or Asbian strata (Cope, 1940; Somerville \& Strank, 1984). This taxon is not restricted to an early Asbian (lower $\mathrm{D}_{1}$ ) age as suggested in George et al., 1976.

The overall faunal assemblage is representative of a shallow shelf environment.

\subsection{4-273.60m : Arundian}

The upper grey/brown dolomitised limestones of this interval are characterised by a paucity of microfauna but some diagnostic corals including Dorlodotia briarti Saleé $(135.94 \mathrm{~m})$, Lithostrotion minus, L. martini? Edwards \& Haime and Syringopora sp. have been found. Together these indicate an Arundian age. Lower down in this succession the less dolomitised limestones contain a rich microfaunal assemblage including Glomodiscus sp., Eoparastaffella simplex (Vdovenko, 1953) and E. restricta Postojalko \& Garini, 1972, confirming an Arundian age. Associated taxa include Brunsia spirillinoides, Palaeospiroplectammina mellina (Malakhova), Glomospiranella $\mathrm{sp}$. and Dainella sp. together with the algae Koninckopora inflata and Solenopora sp. The lowest diagnostic Arundian taxon Glomodiscus occurs at $258.47 \mathrm{~m}$. The occurrence of Koninckopora inflata lower down at $268.98 \mathrm{~m}$ and ?Koninckopora at $269.9 \mathrm{~m}$ indicates that Chadian strata have not been penetrated at these depths. The lowest $3.7 \mathrm{~m}$ of grey/blue limestone and brecciated limestone in the Dinantian succession contain a sparse undiagnostic fauna. From the absence of Chadian microfauna, the lowest $3.7 \mathrm{~m}$ are assumed to be of Arundian age.

The overall palaeoenvironment represented is that of a shallow shelf. The general paucity of fauna may reflect periodically unfavourable conditions for a foraminiferal habitat. The original diversity of the fauna is difficult to assess due to the destruction by dolomitisation of many taxa.

\subsection{0-312.00m (T.D.) : Pre Carboniferous}

These lavas, volcanic breccias and pyroclastic rocks have been dated by K/Ar techniques as Devonian or older (i.e. $383 \mathrm{Ma}$ or older) by Cope (1979). No refinement of this age determination is yet available.

\section{DISCUSSION}

The biostratigraphical results differ markedly from those given by Cope (1973). 


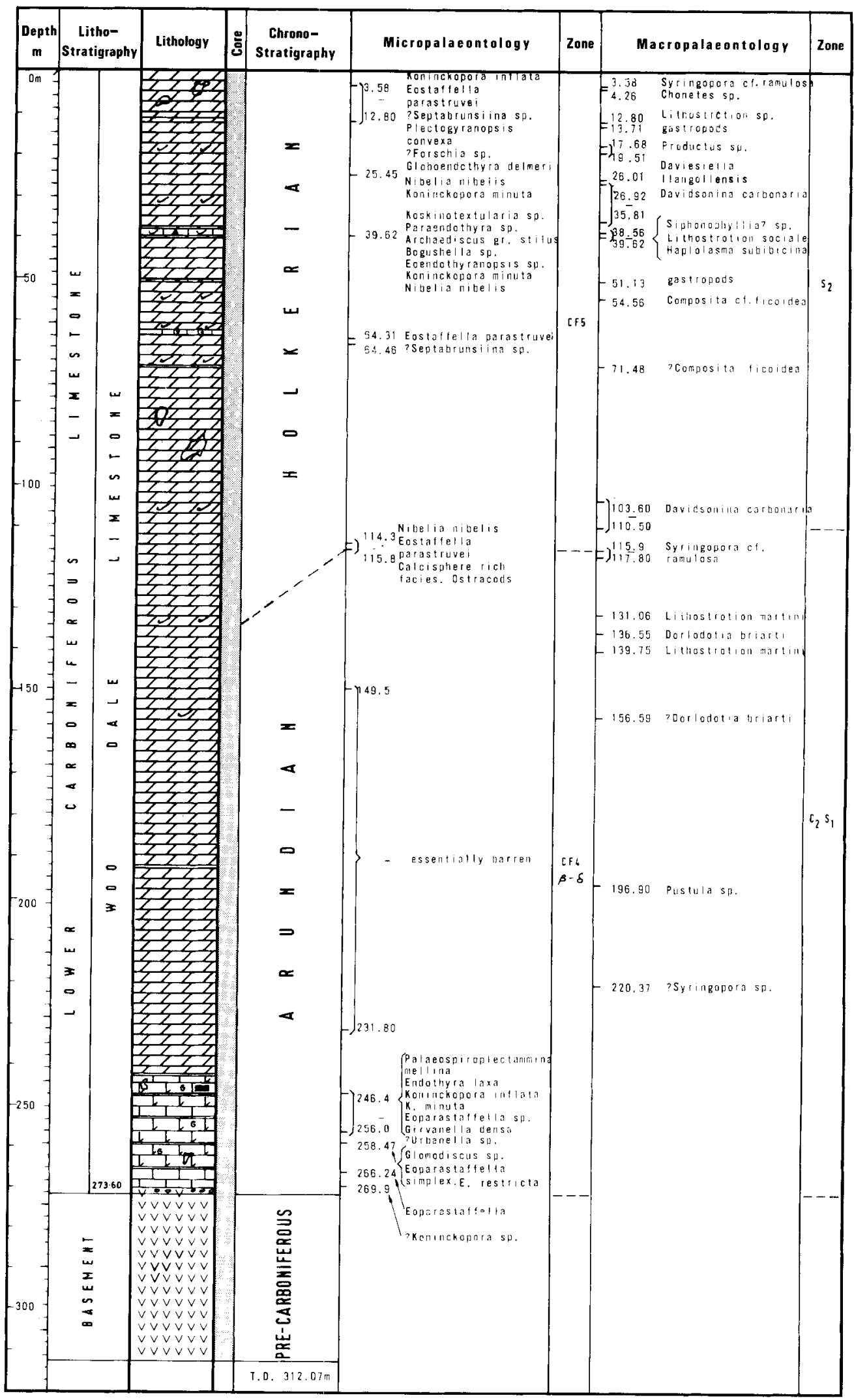

Fig. 3. Biostratigraphy of the Woo Dale Borehole. 


\begin{tabular}{lcc}
\hline & Cope (1973) & Strank (this paper) \\
\hline Holkerian & $\left(\mathrm{S}_{2}\right) 0-110.20 \mathrm{~m}$ & $0-115.97 \mathrm{~m}$ \\
\hline Arundian & $\left(\mathrm{C}_{2} \mathrm{~S}_{1}\right) 110.20-243.20 \mathrm{~m}$ & $135.94-273.60 \mathrm{~m}$ \\
\cline { 3 - 3 } Chadian & & ABSENT \\
\hline Tournaisian? & $243.20-273.60 \mathrm{~m}$ & ABSENT \\
\hline Basement & $273.60-312.00 \mathrm{~m}$ & $273.60-312.00 \mathrm{~m}$ \\
\hline
\end{tabular}

With Holkerian foraminifera recorded down to $115.97 \mathrm{~m}$ and Arundian corals at $135.94 \mathrm{~m}$, the ArundianHolkerian boundary has been placed between these two depths (see Fig. 3).

The major difference in the two biostratigraphical schemes is below the Arundian. Cope records the $\mathrm{C}_{2} \mathrm{~S}_{1}$ zone (Arundian and Chadian) and the underlying ? Tournaisian. Strank (this paper) can find no evidence of limestones older than Arundian. One reason for this discrepancy may be the records of Thysanophyllum pseudovermiculare (McCoy) at $135.94 \mathrm{~m}$ and obscurely at $156.59 \mathrm{~m}$. The specimen at $135.94 \mathrm{~m}$ has been reidentified by Mr. M. Mitchell as Dorlodotia briati, a species diagnostic of Arundian strata (Poty, 1975 \& 1981). Dorlodotia, a fasciculate species is distinguished from the cerioid species Thysanophyllum by the presence of a columella. The taxon Thysanophyllum pseudovermiculare is thought to be characteristic of Chadian rocks. At the time of Cope's (1973) publication, these two taxa had not been distinguished and all such specimens were recorded as Thysanophyllum pseudovermiculare suggesting a Chadian age.

Cope's record of Tournaisian strata is based on the tentative correlation of Solenopora $\mathrm{cf}$. garwoodi clasts with the Solenopora Subzone of Garwood in northern England. Solenopora is not however restricted to Tournaisian strata. The rich foraminiferal assemblage in these beds confirms their Arundian age.

\section{CONCLUSIONS}

The brecciated limestones, lava and pyroclastics in the basal Dinantian sequence indicate deposition of Arundian limestones onto a basement high land area, of pre-Carboniferous age. There is no evidence that any pre-Arundian limestones were deposited in this area. During the early Arundian, a shallow, warm water shelf environment was established in which $137.66 \mathrm{~m}$ of richly bioclastic limestones were deposited. This shelf environment persisted throughout the overlying Holkerian when over $115.97 \mathrm{~m}$ of limestones accumulated. Evidence from surrounding wells and outcrop sections (Aitkenhead et al., in press) suggests that Asbian and Brigantian limestones were originally deposited in the Woo Dale area and have since been eroded away.
In the nearby Eyam district the basement was engulfed by a marine event much earlier in the Dinantian than at Woo Dale. Thick limestones accumulated throughout the Lower Carboniferous from the Courceyan to the Brigantian. Approximately $490 \mathrm{~m}$ of pre-Arundian sediments were deposited at Eyam before the Arundian marine incursion transgressed the Woo Dale area. At Eyam, much thicker Arundian (593.38m) sequences were deposited compared with Woo Dale.

\section{ACKNOWLEDGEMENTS}

The author wishes to thank Prof. F. W. Cope (Clactonon-Sea), Dr. F. M. Broadhurst, Dr. A. Adams (Manchester University), Mr. J. Thomas (Reading University), Mr. M. Davies (BP Eakring) and Mr. P. Daggar (ex I.C.I.) for their assistance in tracing the remaining core samples and thin sections from the Woo Dale Borehole. My gratitude goes to Mr. M. Mitchell (B.G.S. Keyworth) for re-examining and reporting on the coral fauna. The author appreciates the assistance of I.C.I. (Buxton) in granting permission for sampling the borehole and publication of the results. Finally, I acknowledge the use of facilities and assistance with publication from BP Research Centre, Sunbury and BP Petroleum Development Limited, Eakring.

\section{Manuscript received March 1984 \\ Revised manuscript accepted March 1985}

\section{REFERENCES}

Aitkenhead, N., Chisholm, I. D. \& Stevenson, I. P. 1985. Geology of the area around Buxton, Leek and Bakewell. I.G.S. Memoir no. 111.

Cope, F. W. 1940. Daviesiella llangollensis (Davidson) and related forms: morphology, biology and distribution. $J$. Manchr. Geol. Ass., 1, 199-231.

Cope, F. W. 1973. Woo Dale Borehole near Buxton, Derbyshire. Nat. Phys. Sci., 243, 29-30.

Cope, F. W. 1979. The age of the volcanic rocks in the Woo Dale Borehole, Derbyshire. Geol. Mag., 116, 319-320.

George, T. N., Johnson, G. A. L., Mitchell, M., Prentice, J. E., Ramsbottom, W. H. C., Sevastopulo, G. D. \& Wilson, R. B. 1976. A correlation of the Dinantian rocks in the British Isles. Geol. Soc. Spec. Rep. No. $7 ., 87$ pp.

Poty, E. 1975. Contribution à l'ètude du genre Dorlodotia et sa répartition stratigraphique dans le Viséen du bord orientale du Bassin de Namur. Ann. Soc. géol. Belg., 98, 91-110.

Poty, E. 1981. Recherches sur les Tetracorallaires et les Heterocorallaires du Viséen de la Belgique. Meded. Rijks. Geol. Dienst. 35, 1-161.

Somerville, I. D. \& Strank, A. R. E. 1984. Discovery of Arundian and Holkerian faunas from a Dinantian Platform succession in North Wales. Geol. J., 19 (2). 